\title{
BOTANIC GARDENS IN THE ARABIAN PENINSULA
}

\author{
Ahmed H. Al Farhan ${ }^{1}$, Ibrahim M.N. Aldjain ${ }^{2}$, Jacob Thomas ${ }^{1}$, Anthony G. Miller ${ }^{3}$, \\ Sabina G. Knees ${ }^{3}$, Owen Lewellyn ${ }^{4} \&$ Ali Akram ${ }^{1}$
}

\begin{abstract}
Botanic gardens in the Arabian Peninsula and adjacent countries, along with institutions such as museums, universities and research centres, have long played a major role in the exploration, identification and conservation of this region's flora and vegetation. The primary aim of botanic gardens in the past was to study the plant world from the horticultural point of view and to cultivate plants of economic or medicinal importance. However, at present, particularly in arid regions such as the Arabian Peninsula, the activities of botanic gardens are focused primarily on (i) the study and exploration of the region's rapidly vanishing flora, thereby safeguarding gene pools of wild species, and (ii) the assessment and preservation of species that may be of importance to humans and animals for food, medicines, fibre and amenity. Recently established botanic gardens in the region, including the proposed King Abdullah International Gardens in Riyadh and Oman Botanic Garden near Muscat, will enhance existing conservation activities concerning the ailing and rapidly vanishing floristic components of the Arabian Peninsula.
\end{abstract}

\section{INTRODUCTION}

Botanic gardens are based on scientifically documented collections of living and often preserved plants that can be researched by biologists from several disciplines, including taxonomy, ecology, genetics and conservation. In areas where populations of many plant species are on the brink of extinction and in a world of declining biodiversity, botanic gardens can play a major role in plant conservation, initially as safe havens for threatened plants but increasingly as centres for scientific research and education. In addition to the disciplines already mentioned, education can embrace a wide range of subjects including plant geography, biodiversity, ethnobotany, horticulture and landscape design. As the

${ }^{1}$ Professor Doctor Ahmed H. Al Farhan is Director of the King Saud University Botanic Garden. Email: alfarhan@ksu.edu.sa Jacob Thomas is Curator of the Herbarium at King Saud University. Email: jathomas@ksu.edu.sa

Ali Akram is Associate Professor of Environmental Pollution at King Saud University. Email: akram692000@yahoo.com Address: King Saud University, Box 2454, Riyadh 11451, Kingdom of Saudi Arabia.

${ }^{2}$ Dr Ibrahim Aldjain is the General Director of Riyadh Municipality General Administration of Garden and Landscaping and will be Director of the King Abdullah International Gardens in Riyadh.

Address: General Administration of Garden and Landscaping, Riyadh Municipality, PO Box 156444, Riyadh 11778, Saudi Arabia.

Email: abudjain@hotmail.com

${ }^{3}$ Anthony G. Miller is a Researcher on the Flora of Arabia and South West Asia at the Royal Botanic Garden Edinburgh. Email: A.Miller@rbge.org.uk

Sabina Knees is a Researcher on the Flora of Arabia and South West Asia at the Royal Botanic Garden Edinburgh. Email:

S.Knees@rbge.org.uk

Address: Royal Botanic Garden Edinburgh, 20A Inverleith Row, Edinburgh EH3 5LR.

${ }^{4}$ Owen Lewellyn is a conservation biologist at the National Commission for Wildlife Conservation and Development.

Address: PO Box 61681, Riyadh 11575, Saudi Arabia. 
human population becomes more urbanized, botanical gardens are becoming increasingly renowned as sources of knowledge as well as important recreational centres offering city dwellers a sense of connection with the natural environment.

The Arabian Peninsula is a region of diverse topography ranging from the vast, rainless, sand and rock deserts such as the Rub' al-Khali and the Great Nafud, to mist-covered mountains reaching over $3,000 \mathrm{~m}$ along the escarpment of the southwest. Generally, all the mountains in the south of Arabia benefit from rain and low clouds during the northeast and southwest monsoons - this leads to the development of rich woodland in some areas, particularly the seaward-facing slopes of the Dhofar mountains in Oman and Yemen and the upper slopes of the Heggier mountains on Socotra. However, there are no permanent rivers. Topographically, the Peninsula can be divided into two: the Arabian Shield to the northwest and the Arabian Platform to the southeast. As far as floristic biogeography is concerned, the Arabian Peninsula represents a crossroad and the species composition is a mix of Holarctic elements from the north and Palaeotropical elements from the south (Miller \& Cope, 1996). Three main phytogeographical areas are represented in the Peninsula: the Saharo-Sindian Regional Zone, the Somalia-Masai Regional Centre of Endemism and the Afromontane Archipelago-like Regional Centre of Endemism. Floristic elements from surrounding phytochoria also extend into Arabia, with enclaves of Mediterranean species occurring in the mountains of western Saudi Arabia. Similarly, Irano-Turanian elements occur in the mountains of northern Oman.

The region contains approximately 3,418 species in 144 families, of which roughly 357 species (11.5\%) are endemic, excluding Socotra which has 307 endemics (37\%) (Miller \& Morris, 2004). Table 1 shows the number of species, number of endemics, percentage endemism and surface areas of countries in the Arabian Peninsula. Vegetation in the Peninsula is broadly divided into woodland, bushland, thicket, shrubland, scrub, mangrove and desert with seasonal annuals. The west-facing slopes of mountains in Saudi Arabia, Yemen and Oman are more or less densely vegetated with areas of dense Juniperus woodland at higher altitudes. Although the region has its own endemic species, the influence of East African and Mediterranean floras is quite evident in many parts of the Peninsula, especially along the western escarpment mountains and plains. Approximately $70 \%$ of the species are found in the mountains of southern, southwestern and northwestern regions. However, the vegetation in general and the composition of species in the northwestern mountains is relatively sparse and highly degraded compared to that of the southern and southwestern mountains. The area is also renowned for its ancient cultivated terraces where people followed centuries-old traditional agricultural practices across the mountains of the southwest. Several important millets, cereals and cash crops such as coffee originate here (Zohary \& Hopf, 2000). 


\begin{tabular}{|l|l|l|l|c|}
\hline \multicolumn{1}{|c|}{ Country } & \multicolumn{1}{c|}{ No. of species } & Endemic plants & \multicolumn{1}{c|}{ \% endemism } & Area (sq.km) \\
\hline Saudi Arabia & c. 2,240 & 51 & 2.27 & $2,400,000$ \\
\hline Yemen & c. 2,000 & 149 & 11.5 & 536,869 \\
\hline Socotra & 825 & 307 & 37 & 3,800 \\
\hline Oman & 1,200 & 78 & 6.5 & 270,000 \\
\hline UAE & 268 & 0 & 0 & 75,000 \\
\hline Qatar & 312 & 0 & 0 & 11,500 \\
\hline Bahrain & 280 & 0 & 0 & 660 \\
\hline Kuwait & 280 & 0 & 0 & 24,000 \\
\hline
\end{tabular}

Table 1. A list of countries based on the size of the flora and percentage endemism.

The Arabian Peninsula is home to a significant number of species of ethnobotanical interest, some of which are edible, medicinal, aromatic, fibre- or oil-yielding or simply ornamental. Research has been carried out in the past to establish either the medicinal effect or the economic importance of a number of wild plants, such as Carthamus tinctoria (oil, dye), Commiphora spp. (gum), Achillea fragrantissima, Ephedra alata, Peganum harmala, Ricinus communis (medicine), Moringa peregrina (essential oil) and Artemisia spp. (perfumes). Although the use of plants or plant-products in the region is extensive, the importance of a few species, along with knowledge about them and their uses, has been deeply associated with the tradition and culture of the tribal communities of the Arabian Peninsula. Species such as Aloe spp. (glucosides), Boswellia sacra, Commiphora spp. (oleo-gum resins), Medicago sativa (forage), Beta vulgaris, Eruca sativa (edible leaves), Hordeum vulgare, Panicum spp., Triticum spp., Sorghum vulgare (cereals), Ziziphus spina-christi, Tamarix aphylla (timber) and Catha edulis (stimulant) are very popular among the tribal communities.

\section{FACTORS AFFECTING PLANT DIVERSITY}

Though the Arabian Peninsula possesses a variety of vegetation types and considerable species diversity, the conservation and sustainable development of these natural resources present a great challenge for agencies such as the National Commission for Wildlife Conservation and Development (NCWCD). The Arabian Peninsula, like many other arid regions, faces severe genetic erosion due to desertification caused by overgrazing, poor agricultural practices, inappropriate irrigation practices resulting in the salination and alkalization of agricultural land, clearance of woodland for fuel or timber, charcoal production, invasive alien plants and the unsustainable use of its natural resources.

It is estimated that $73 \%$ of the Earth's arable land is either human dominated or partially or totally disturbed due to unsustainable land practices. By the year 2025 the world population is expected to reach about 8.3 billion, compared to the current estimate of around 6 billion. In the case of the Arabian Peninsula, where the growth 
rate is considered to be one of the highest in the world, the population of all member countries is expected to double by 2025 . As the human population grows, demand on the Earth's resources will also increase. In order to meet the demands of the growing population, new townships, industrial estates and agricultural lands will be developed or extended in all countries of this region. In most cases, these expansions usually extend into vegetation-rich areas, valleys and wetland ecosystems. This will result in the loss of several habitats essential for the survival of a significant number of rare or endangered species, or result in the destruction of an entire plant diversity hotspot. Overgrazing by goats, camels, cattle and sheep is one of the major causes of desertification in the region, especially in Saudi Arabia where traditional pastoral practices have vanished. Transporting herds to vegetation-rich areas and installation of water supplies, as well as other required amenities, to the new camps have all aggravated the problem. The prevailing faulty agricultural practices are another problem seriously affecting the vegetation of this region. The expansion of agricultural fields, the practice of abandoning existing fields due to alkalization or salination as well as the excessive use of herbicides and pesticides are also affecting the vegetation structure and thereby allowing weeds and other non-palatable species to flourish in unattended lands.

Even though the above mentioned factors have some negative impacts on ecosystems, the principal reasons for the loss of plant diversity in the Arabian Peninsula are thought to be excessive drought and climate fluctuations prevailing in the region. As per current estimates, the number of endangered or rare species in Saudi Arabia alone is estimated to be around 500 species and the number of species added to the endangered list is increasing every year. Governments in the region are doing everything possible to stop this trend by declaring sites with high species diversity as protected areas. In situ conservation through protected area management systems has limitations, however, since in the majority of sites the protection is vegetation-specific rather than species-specific. Botanic gardens around the world, through effective ex situ conservation methods such as tissue culture, can be effective in the conservation of ailing populations of rare and endangered species.

\section{HISTORY}

The significance of botanic gardens in the conservation and development of the flora of a country or region cannot be overstated. The development of botanic gardens in ancient times was a gradual process. In prehistoric times, man had begun to cultivate plants which were then known to him as useful for food, fuel, housing or medicine. In the Middle Ages physic gardens became associated with medical institutes and universities, whilst in many countries and civilizations, gardens were a prominent feature of religious places and palaces. According to literature sources, the contribution of botanic gardens to science started during the time of Theophrastus (300 to $200 \mathrm{BC}$ ). The earliest botanic gardens existed in Mesopotamia and Egypt for growing herbs, edible plants and ornamental plants for pleasure. The first modern botanical garden was created in Pisa 


\section{Saudi Arabia}

Harrat al Harrah

Al-Khunfah

Mahazat as-Sayd

'Uruq Bani Ma'arid

Majami'al-Hadb

At-Taysiyah

Al-Jandaliyah

Nafud al-'Urayq

Saja Um Al-Rimth

Asir National Park

\section{Oman}

\section{Nature Reserves}

Arabian Oryx Sanctuary

As Saleel Natural Park

Dimanyiat Islands Reserve

Jabal Samhan Reserve

Khawrs Reserves

Qurum Nature Reserve

Turtles Reserve

Wadi As Sarin Reserve

UAE

Merawah Island

$\mathrm{Bu} \mathrm{Al}$ Siaief

Wadi Wuraya Mountain

\section{Yemen}

\section{National Parks}

Jabal Bura valley forest

Marine National Parks

Zuqur islands

Marine Parks

Ras Isa

Nature Reserves

Hamaderoh

Ma'alih

Muqadrihon

Shihali

Reserves

Dhamar Montane Plains Mahjur

Eastern region (Mahrah)

Jabal al-Ara' is

Kumran islands

Other Protected Areas

Al Kadan, Dobera Parkland, Tihamah

Al Khawkhah
Ibex Reserve

Al-Tubayq

Farasan Islands

Raydah

Umm al-Qamari

Al Khawkhah-Bab el Mandab

Al Luhayyah region

Al Mahwit woods

Al Manzar-Ghilayfiqah

Al Mujaylis-Al Fazzah lagoons

Al Mukha

Al Qutay-Jabal Bura', Tihamah

Al Urj-Hodeidah

Al Zuhrah

Almahr

Bahr Ibn Abbas

Bura Community Protected Area

Dhubab

Hidhran marshes

Humar island

Isa Peninsula

Jabal an Nabi Shu'ayb

Jabal Lawz forest

Jabal Sabir-Wadi Thabad wadis

Khawr north of $\mathrm{Hab}$

Marsa al Fajrah-Ar Ru'aya

Mocha/Bab al Mandib Tihama plain area

Nishtun

North Al Mawahij

North Ibn Abbas

Oreste point

Perim Isles

Qatabah-Abu Zahr

Ra's Abu Quizara

Ra's Katanib island

Shibam/Kawkaban escarpment

Socotra island

South Al Mukha-South Dhubab

South Yakhtul-North Al Mukha

Ta'izz woods

Ukban Island

Uqban (Ukban) islands

Wadi Duba forest

Wadi Hudayn (Bura) forest

Wadi Mawr, Tihamah

Wadi Rima estuary

Wadi Siham

Wadi Suq'Abs, Tihamah

Wadi Zabid catchment

community protected area

Zubayr islands

Table 2. National Parks, protected areas and Nature Reserves in the region. 
in 1543. Subsequently several other botanic gardens were established in various parts of the world. Among these, the Royal Botanic Garden Edinburgh, one of the oldest in the UK, was established as a physic garden in 1670 and currently grows about 15,681 species; the Royal Botanic Gardens, Kew was founded some 90 years later in 1759 and grows about 11,234 species (Rae et al., 2006). Similarly botanic gardens of various types were created in parts of the Middle East. The 'Hanging Gardens of Babylon' were one such important garden - widely regarded as one of the wonders of the ancient world. In Arabia, however, the cultivation of food and medicinal plants has been known for the past 3,000 years. As knowledge about plants became increasingly scientific, several pleasure gardens were transformed into botanical gardens. These not only became the hub of advanced learning but began to play a crucial role in the financial and cultural needs of a number of nations.

Traditionally, the Arabian Peninsula and adjacent regions have an extensive experience in protecting their natural plant wealth through a protection system called the 'hema' or 'hima' system (Gari, 2006). Hema is an Arabic word which means an area under protection. The practice of these systems dates back to the pre-Islamic era, and probably goes back even as far as 2,000 years. It was developed for the sustainable use of scarce renewable resources. These sites were usually controlled by tribal chiefs and were mostly used for grazing during drought seasons and on other occasions for uses such as bee-keeping and also for the protection of its meagre tree wealth. All other activities such as collecting fodder and wood cutting were banned for most of the time and if allowed, these were done with restrictions and regulations governed by those who had established or managed the hema. According to surveys conducted in 1969, there were about 3,000 hema in Saudi Arabia alone. However, by 1984 this number was reduced to 71. As and when the economy improved, most of the tribal people moved from their desert dwelling places to more urbanized areas in search of a better lifestyle. The hema system has now been replaced by modern protected areas and a Natural Parks system. Even though the age-old hema systems in the region have largely broken down, the past and present activities of the conservation agencies in the region have curtailed the loss of biodiversity to a certain extent. A significant number of areas have been identified and declared as protected areas and several are in the process of being declared such. Among these are at least a few plant diversity hotspots.

\section{BOTANIC GARDENS AND CONSERVATION}

The Conservation Strategy for botanic gardens was developed in 1989 by Botanic Gardens Conservation International (BGCI). The global distribution of botanic gardens is not directly correlated with the regional needs for conservation, as most species occur in tropical or sub-tropical countries where there is only a negligible number of botanic gardens in relation to high levels of species diversity (IUCN-BGCS \& WWF, 1989). At present, the majority of gardens are situated in the northern hemisphere where floristic diversity is either low or impoverished. In 1992 the Convention on Biological Diversity 
(CBD) was signed by approximately 175 countries at the United Nations Conference on Environment and Development (UNCED) in Rio de Janeiro, Brazil. The Earth Summit provided opportunities for botanic gardens and networks to become involved in global and national conservation issues and the sustainable use of biodiversity (Parson et al., 1992). Botanic gardens should assist governments in meeting their objectives on maintaining and conserving biodiversity. Approximately 20 targets were developed for botanic gardens at the second World Botanic Gardens Congress held in Barcelona, Spain in 2004. These targets, intended for 2010, provide a way of measuring the objectives of the Global Strategy for Plant Conservation and the International Agenda for Botanic Gardens in Conservation (Wyse-Jackson \& Sutherland, 2000), facilitating botanic gardens to execute the articles outlined in the CBD. The articles of the CBD have provided the impetus and motivation for governments to catalogue and protect their own plant diversity.

BGCI provides a means for member gardens to share information on conservation matters, their activities and programmes. This loose link is vital as botanic gardens need to share information with each other as well as with the outside world (Nature Editorial, 2006). Botanic gardens remain important as repositories of information on local floras and centres of scientific excellence for studies including monographic work. These gardens also provide facilities for the collection of living plant material and for biosystematic studies. They are widely recognized for the roles that they play in conservation, sustainable management and the utilization of plant genetic resources. Botanic gardens support conservation in two ways: their staff and associates can study plant diversity in a region, and make conservation assessments of threatened species which can then be cultivated for further study or future reintroductions. Preserving genetic diversity is another important role of botanic gardens. Botanic gardens are not just gardens; rather they are knowledge centres which also include greenhouses, herbaria, libraries and research laboratories. They also provide living material for botanical research. Scientists in botanic gardens are generally regarded as a good source of reliable, factual information on everything from climate change to genetically modified organisms (Marris, 2006).

The International Association of Botanic Gardens, which was established in 1962, meets regularly to discuss the activities of botanic gardens. They usually recommend the expansion of activities of gardens such as supply of material and information for research in all botanical disciplines.

\section{Summary of roles of botanic gardens}

Botanic gardens and their networks support and contribute to the sustainable use of plant resources. In addition they can:

1. Increase their participation as partners in formal comprehensive recovery planning and plan implementation that is integrated with state, provincial and federal agencies for species in their regions. 
2. Actively seek ways to work collaboratively to support the conservation of threatened natural areas, habitats and ecosystems locally, regionally and internationally.

3. Contribute to conservation and preservation of economically and socially important plant diversity.

4. Recognize their role in invasive and alien species management and education.

5. Expand support and contribute to pure and applied conservation biology research for the conservation of plant diversity.

6. Contribute to the awareness and protection of cultural and local indigenous uses and associated knowledge of plants.

7. Promote public education and awareness about plant diversity.

8. Strengthen the promotion and partnerships of existing public-awareness campaigns for plant diversity and conservation.

9. Be contributors to national and international capacity for conservation and sustainable use of plant diversity.

\begin{tabular}{|l|l|l|}
\hline \multicolumn{1}{|c|}{ Country } & No. of established gardens & \multicolumn{1}{c|}{ Proposed projects } \\
\hline Algeria & 3 & 0 \\
\hline Bahrain & 0 & 0 \\
\hline Djibouti & 0 & 0 \\
\hline Egypt & 6 & 0 \\
\hline Iran & 6 & 4 \\
\hline Iraq & 1 & 0 \\
\hline Jordan & 0 & 1 \\
\hline Kuwait & 1 & 0 \\
\hline Lebanon & 0 & 2 \\
\hline Libya & 1 & 0 \\
\hline Morocco & 3 & 0 \\
\hline Oman & 2 & 1 \\
\hline Palestinian Territories & 2 & 0 \\
\hline Qatar & 0 & 1 \\
\hline Saudi Arabia & 2 & 1 \\
\hline Syria & 0 & 1 \\
\hline Tunisia & 3 & 1 \\
\hline UAE & 0 & 1 \\
\hline Yemen & 0 & 1 \\
\hline Yemen - Socotra & 0 & 1 \\
\hline Table & 0 & 1 \\
\hline
\end{tabular}

Table 3. Established and proposed botanic gardens in Arabian countries. 
Since the region's plant diversity habitats are shrinking at an alarming rate, botanic gardens in the Arabian Peninsula have a greater role to play in the coming years in the conservation and preservation of the area's natural plant wealth. The eight most important gardens in the region are listed in Table 4. According to Barton Willmore, the designers of the King Abdullah International Gardens project, the proposed gardens should

"become a leading focus of mankind's understanding of the process, consequence and study of climate change, capturing and displaying extraordinary ecotopes from history and from the present day, and presenting the choices that are available to us. Our plan is to demonstrate these principles of sustainable development to the indigenous people of the region and the international visitors who will be drawn to this unique facility in the heart of the desert countries. In summary, we feel that gardens should appeal to both the citizens and international visitors on many levels".

According to the estimates given by BGCI (Wyse-Jackson \& Sutherland, 2000), there are about 2,000 botanic gardens throughout the world, measuring from a fraction of a hectare to over a thousand hectares. These botanic gardens receive approximately 200 million visitors every year. Most gardens have prioritized public education regarding the importance of botanic gardens and the role played by them in the protection of endangered plants and their habitats. The global mission of botanic gardens worldwide for conservation is summarized as follows:

\begin{tabular}{|c|c|c|c|c|c|}
\hline Garden name & Country & City & Code & $\begin{array}{l}\text { Associated } \\
\text { institution }\end{array}$ & $\begin{array}{c}\text { Year } \\
\text { established }\end{array}$ \\
\hline $\begin{array}{l}\text { King Saud University Botanic } \\
\text { Garden }\end{array}$ & $\begin{array}{l}\text { Saudi } \\
\text { Arabia }\end{array}$ & Riyadh & KSU & $\begin{array}{l}\text { King Saud } \\
\text { University }\end{array}$ & 1983 \\
\hline $\begin{array}{l}\text { Madinat Yaubu Al-Sinaiyah } \\
\text { Botanic Garden }\end{array}$ & $\begin{array}{l}\text { Saudi } \\
\text { Arabia }\end{array}$ & $\begin{array}{l}\text { Yaubu } \\
\text { Al-Sinaiyah }\end{array}$ & & Municipality & \\
\hline $\begin{array}{l}\text { National Commission for Wildlife } \\
\text { Conservation and Development }\end{array}$ & $\begin{array}{l}\text { Saudi } \\
\text { Arabia }\end{array}$ & Riyadh & NCWCD & NCWCD & 1987 \\
\hline $\begin{array}{l}\text { Sultan Qaboos University Botanic } \\
\text { Garden }\end{array}$ & Oman & Al-Khod & SQAK & $\begin{array}{l}\text { Sultan } \\
\text { Qaboos } \\
\text { University }\end{array}$ & 1989 \\
\hline Oman Botanic Garden & Oman & Muscat & & & 2008 \\
\hline Natural History Botanic Garden & Oman & Muscat & MUSCA & $\begin{array}{l}\text { Natural } \\
\text { History } \\
\text { Museum }\end{array}$ & \\
\hline Sharjah Botanical Gardens & UAE & Sharjah & SHARJ & & 1997 \\
\hline Kuwait Botanic Garden & Kuwait & Safat & SAFAT & & \\
\hline
\end{tabular}

Table 4. Important gardens of the Arabian Peninsula. 
- Stem the global loss of plant species and their genetic diversity.

- Prevent further degradation of the world's natural environment.

- Raise public understanding of the value of plant diversity and the threats it faces.

- Implement practical action for the benefit and improvement of the world's natural environment.

- Promote and ensure the sustainable use of the world's natural resources for present and future generations.

\section{CASE STUDY}

\section{King Saud University Botanic Garden}

The botanic garden associated with King Saud University, the first of its kind in Saudi Arabia, was established in 1983 when the University moved to its new campus in Dereiya, Riyadh. It constitutes an integral part of the Department of Botany \& Microbiology at King Saud University, and its main purpose is to provide living plant material, experimental plots and practical help for botanical teaching and research in the department. At the same time it also serves as an important educational resource for the general public (Fig. 1). The garden (acronym - KSU) covers an area of about $10,000 \mathrm{~m}^{2}$ and is surrounded by walls to prevent any unwanted intrusions. The activities of the garden, which remained dormant for about a decade or so, were revitalized in 1994 through the generous support of the University authorities.

Through the effects of climate change, habitat destruction and the spread of invasive alien species, the Arabian flora faces unprecedented challenges. Projects based in the Central Region of Saudi Arabia and nearby regions are supported by KSU, which has a seed bank and propagation facilities as well as provides administrative and curatorial support. The main objectives of the King Saud University Botanic Garden are to:

- protect rare and endangered plants

- preserve genetic diversity

- help ensure the utilization of plant species and the ecosystems in which they occur

- make people aware of the importance of botanic gardens and train them in the planning, planting and protection of such gardens

- persuade landscape architects and municipal authorities to use native plants in their gardening programmes whenever and wherever suitable

- supply material for various purposes to remove or reduce pressure of collecting wild plants from nature

- grow those species with recalcitrant seeds that cannot be maintained in a seed store

- make available material for conservation, education and display

- produce material for reintroduction, reinforcement, habitat restoration and management. 


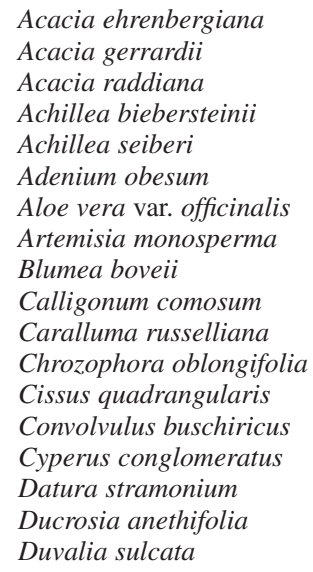

\author{
Huernia saudi-arabica \\ Lavandula pubescens \\ Lawsonia inermis \\ Leptadenia pyrotechnica \\ Mimusops laurifolia \\ Panicum turgidum \\ Plectranthus asirensis \\ Retama raetam \\ Rhus tripartita \\ Salvia spinosa \\ Senna alexandrina \\ Senna italica \\ Senna occidentalis \\ Solanum incanum \\ Solanum sepicula \\ Tamarindus indicus \\ Ziziphus spina-christi
}

Table 5. Plants in cultivation at King Saud University Botanic Garden (KSU).

At present the garden contains a significant number of wild species, ranging from endangered and rare plants to economically important plants. The garden also has a pool for the cultivation of aquatic plants. Some of the species currently in cultivation are listed in Table 5.

\section{PROPOSED GARDENS IN THE ARABIAN PENINSULA}

The National Commission for Wildlife Conservation and Development (NCWCD) has planned the development of a major national botanic garden in Riyadh. A feasibility study was conducted in the late 1990s by a team of experts led by Peter Wyse-Jackson, then Secretary General, at BGCI. At present, the Commission maintains a small collection of rare and endangered plants in the garden surrounding its main building.

\section{King Abdullah International Gardens, Riyadh}

Barton Willmore, a leading British designer, in a joint venture with civil engineers Buro Happold, has been appointed to create a 160 hectare futuristic botanical garden: the King Abdullah International Gardens (KAIG) in southwest Riyadh, Saudi Arabia. The Natural History Museum and The Eden Project, in the UK, will act as advisors to the project.

The $\$ 170$ million project, which draws on expertise from the Natural History Museum and specialist sustainable development design group 'Emergy', was commissioned by the Mayor of Riyadh and funded by contributions from business and individuals in the city. The 160 hectare botanical garden scheme and leisure destination will be a keystone of the city's growth and intends to provide a new tourist and educational centre for both Saudis and international visitors. The centrepiece of Barton Willmore's proposal is a 20 acre palaeobotanic building, formed as two interlocking crescents which accommodate a sequence of controlled environments (Fig. 2). Each environment allows 

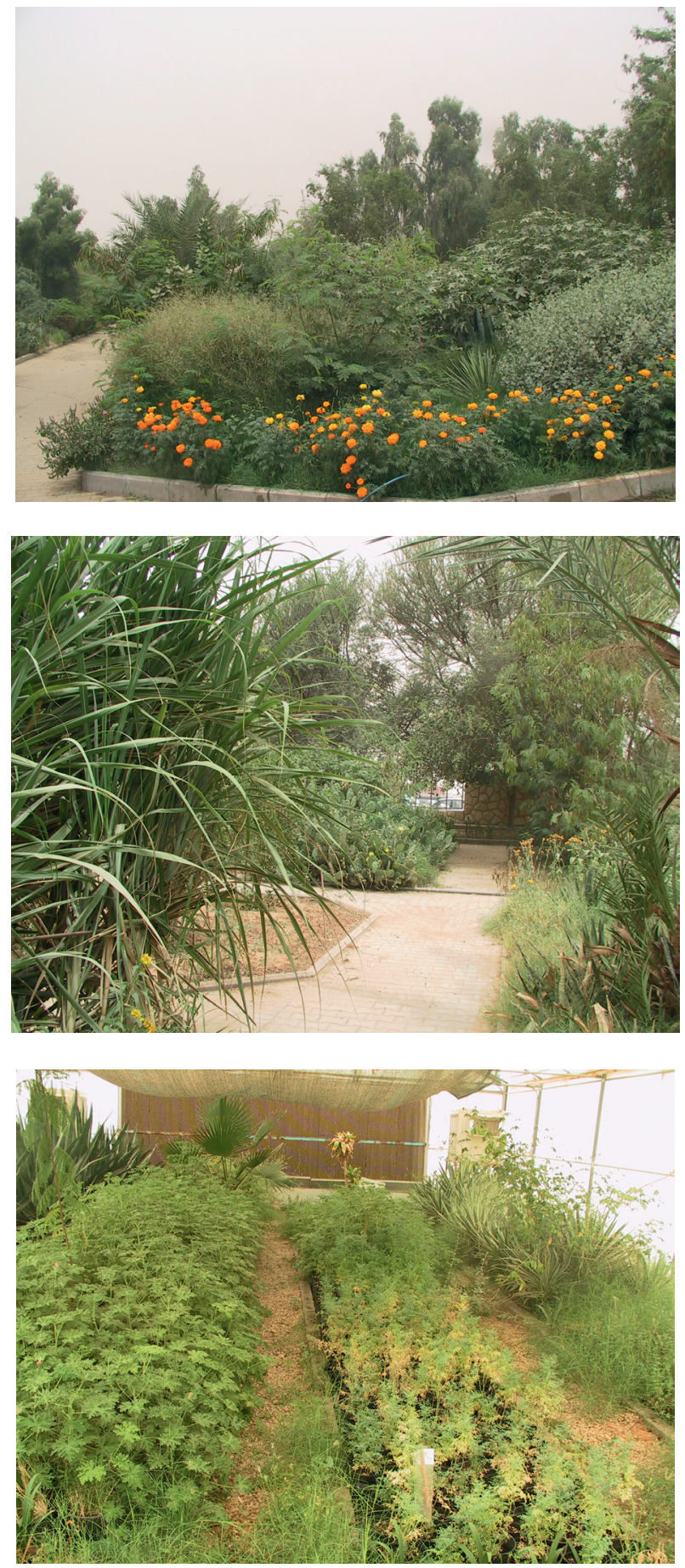

Fig. 1 Images of King Saud University Botanic Garden (KSU). Photos: KSU. 
visitors to travel through time and recreates pre-existing ecosystems based on actual environments which have occurred on this precise piece of land through time. The King Abdullah International Gardens have been designed to become a world-leading focus of mankind's understanding of the process, consequence and study of climate change, capturing and displaying extraordinary ecotopes from history and from the present day, and presenting the choices that are available to us. The project is due to be completed for the spring of 2010 as a gift to Custodian of the Two Holy Mosques, King Abdullah Bin Abdulaziz. The proposed garden consists of:

1. Palaeobotanical Gardens

Garden of Choices

Devonian Garden

Carboniferous Garden

Jurassic Garden

Cretaceous Garden

Cenozoic Garden

Pliocene Garden

2. Scientific Gardens

The Aviary

Discovery Garden

The Maze

Physic Garden

Butterfly Garden

Sound \& Light

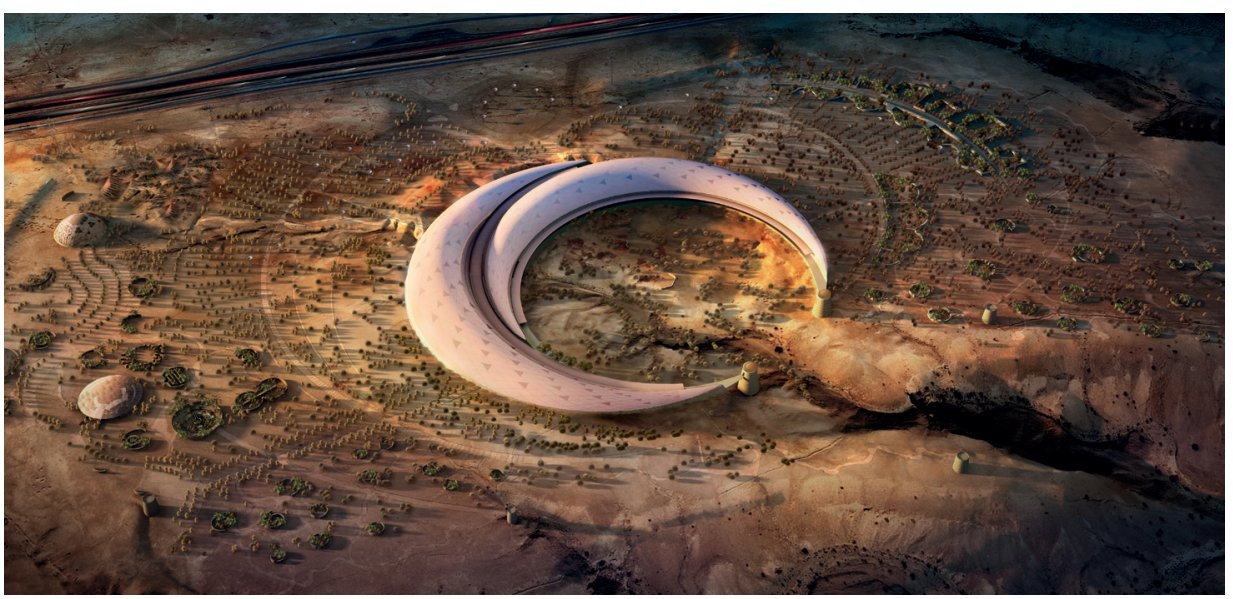

Fig. 2 Proposed King Abdullah International Gardens, Riyadh. Image: Barton Willmore. 
3. Wadi Garden

\section{Water Garden}

\section{Other proposed gardens}

Since developments in the region are rapid, the conservation of its natural resources is also being addressed by other governments. UNESCO and the Doha Government are gathering a team of landscape architects, botanists, ecologists and religious scholars to develop a network of botanic gardens in the Arabian Peninsula which focus on the regional flora, environment, cultural heritage and education. In addition to the components of the natural flora, other plants, particularly medicinal ones, mentioned in the Holy Quran which were cited by the Prophet Mohammed, PBUH, will also be grown in the garden. Additionally, important species from regional ecosystems such as coastal regions and mountains, sandy areas, rock and gravel deserts, wadis, and aquatic habitats together with a number of agricultural plants will be grown in the gardens. At present UNESCO's Office in Doha is putting this project into practice in Sharjah, UAE. H.H. Dr Sheikh Sultan bin Mohammed Al Qasimi, the ruler of Sharjah, invited UNESCO to develop a masterplan for a garden. UNESCO, in conjunction with the Qatar Foundation, is also developing a masterplan for the ex situ conservation of the flora of Qatar. The Sultanate of Oman is also currently planning a botanic garden for the protection and display of all its native plant species and their associated habitats. The proposed garden will be established on a 423 hectare site near Muscat. The masterplan for the project has been completed by an international consultant and the detailed design has been awarded to consultants in Madrid with advice from BGCI, the Royal Botanic Garden Edinburgh and the Fairchild Tropical Garden.

Pre-existing and recently established botanic gardens in the Arabian Peninsula can take significant steps to address the various issues related to the loss of plant diversity in the region. These gardens will also work closely with BGCI for the promotion and conservation of the local flora.

\section{ACKNOWLEDGEMENTS}

The authors acknowledge with thanks the permission given by Barton Willmore to reproduce Fig. 2.

\section{REFERENCES}

GARI, L. (2006). A history of the Hima Conservation System. Environment and History, 12, 213-228.

IUCN-BGCS \& WWF (1989). The Botanic Gardens Conservation Strategy. IUCN Botanic 
Gardens Conservation Secretariat, Kew, Richmond, UK and WWF and IUCN, Gland, Switzerland.

MARRIS, E. (2006). Gardens in full bloom. Nature, 440, 13 April, 860-863.

MILLER, A.G. \& COPE, T.A. (1996). Flora of the Arabian Peninsula and Socotra Volume 1. Edinburgh University Press. 586 pp.

MILLER, A.G. \& MORRIS, M. (2004). Ethnoflora of the Soqotra Archipelago. Royal Botanic Garden Edinburgh. 776 pp.

NATURE EDITORIAL (2006). The constant gardeners. Nature, 440, 13 April, 845.

PARSON, E.A., HASS, P.M. \& LEVY, M. (1992). A summary of major documents signed at the earth summit and global forum. Environment, 34(4), 12-15, 34-36.

RAE, DAVID et al. (2006). Catalogue of Plants 2006. Royal Botanic Garden Edinburgh.

WYSE-JACKSON, P.S. \& SUTHERLAND, L.A. (2000). International Agenda for Botanic Gardens in Conservation. Botanic Gardens Conservation International, UK.

ZOHARY, D. \& HOPF, M. (2000). Domestication of plants in the Old World. Third edition. Oxford University Press. 316 pp. 
